\title{
SEASONAL CHANGES IN THE TESTICULAR BLOOD FLOW OF SEASONALLY BREEDING MAMMALS: DORMOUSE, GLIS GLIS, FERRET, MUSTELLA FURO, AND FOX, VULPES VULPES
}

\author{
JANIE JOFFRE AND M. JOFFRE \\ Centre d'Etudes Biologiques des Animaux Sauvages (CNRS), \\ Villiers en Bois-79-Beauvoir, France, and Laboratoire de Physiologie Comparée, \\ Faculté des Sciences Fondamentales et Appliquées-86-Poitiers, France
}

(Received 14th Fune 1972)

\begin{abstract}
Summary. The testicular capillary blood flow of three seasonally breeding mammals has been measured, using the radioactive inert gas clearance technique at approximately monthly intervals throughout the year. Mean blood-flow values \pm S.E.M. $(\mathrm{ml} / \mathrm{min} / 100 \mathrm{~g})$ recorded in seven dormice were minimal $(18 \cdot 3 \pm 1 \cdot 2)$ from December to February and maximal $(41 \cdot 6 \pm 1 \cdot 7)$ in June; in eight ferrets, they were minimal $(21 \cdot 3 \pm 1 \cdot 5)$ in July and maximal $(35 \cdot 2 \pm 2 \cdot 1)$ from January to March; in thirteen foxes, they were minimal $(21 \cdot 3 \pm 2 \cdot 1)$ from May to September and maximal $(68.3 \pm 3 \cdot 6)$ in January. The seasonal patterns of testicular capillary blood flow vary greatly between species: they are more obvious in the fox and dormouse. In these two species, the seasonal morphological modifications of the testes are more important. The testicular capillary blood flow is maximal when the testes are in an active state and minimal during the inactive period.
\end{abstract}

\section{INTRODUCTION}

The development of the germinal epithelium is accompanied by changes in the pattern of the microcirculation of the rat testis (Kormano, 1967). As the initiation of spermatogenesis is under pituitary control, it has been suggested that 'the vascular growth may be under the control of gonadotrophins or other anterior pituitary hormones' (Waites \& Setchell, 1969; Setchell, 1970). Nevertheless, it is generally agreed that gonadotrophins have no immediate effect on the total venous blood flow through the testes of dogs, rams, boars and stallions (Lindner, 1961; Eik Nes, 1964) or on the testicular capillary blood flow of rams (Setchell, 1970).

In the present study, changes in the testicular capillary blood flow were determined in wild mammals in which seasonal changes in the testes are under the control of pituitary hormones. 
Animals

The animals used were three species of wild mammals: two Carnivora, the fox, Vulpes vulpes, and the ferret, Mustella furo, and a hibernating rodent, the dormouse, Glis glis. Thirteen foxes $(3.8$ to $7 \mathrm{~kg}$ ), eight ferrets ( $750 \mathrm{~g}$ to $2 \mathrm{~kg}$ ) and seven dormice (110 to $270 \mathrm{~g}$ ) were used. (The lowest weights were recorded at the beginning of the experiments, the heaviest weights at the end.) These animals were caught in South Western and Mid-Western France and were kept in captivity under the natural photoperiod, with a diet suitable for each species; the period of captivity was no longer than $1 \frac{1}{2}$ years. Foxes were maintained at seasonal temperatures, ferrets and dormice at 18 to $20^{\circ} \mathrm{C}$. In winter, dormice are usually in hibernation, but indoors and at 18 to $20^{\circ} \mathrm{C}$, some of them were actually in hibernation and others presented only the symptoms of hibernation.

After light anaesthesia with ether, the animals received an intraperitoneal injection of pentobarbitone sodium (fox, $15 \mathrm{mg} / \mathrm{kg}$ body wt; ferret, $20 \mathrm{mg} / \mathrm{kg}$ body wt; and dormouse, $25 \mathrm{mg} / \mathrm{kg}$ body wt). During experiments, the animals were placed on their backs on an operating table and tilted 'head up' at an angle of $7^{\circ}$ to the horizontal.

\section{Measurement of capillary blood flow}

The capillary blood flow in the testis was measured by the radioactive inert gas clearance technique previously used to study nutrient blood flow of many organs and applied to the testis by Setchell, Waites \& Thorburn (1966). About $30 \mu \mathrm{Ci}$ xenon 133 (Xe 133-S ; CEN, Belgium) in 0.01 to $0.02 \mathrm{ml}$ saline solution $(0.9 \%$ sodium chloride) were injected directly into the testicular parenchyma, through the scrotum, with an intradermal needle (26-G). The disappearance rate of the isotope was measured by a scintillation probe with a sodium iodide crystal. The output from the probe was led into an Analyser (SA 41 Intertechnique). In order to keep as closely as possible to the ideal method described by Hyman (1960) and to be sure that this method was reproducible, the labelled compound was introduced into a relatively avascular area of the testis and it was imperative that the arrangements of the tissue and the counting system were held constant.

In all cases, second order exponential curves were obtained, indicative of the existence of two compartments. In the rat, it has been proved that testicular blood flow is given by the first fast component of clearance curves and that the second slow component belongs to the epididymal fats (Joffre \& Joffre, 1971). In wild mammals, a procedure of compartment analysis made it possible to determine the mass and anatomical nature of each compartment (Joffre, 1971). It was usually possible to link the first fast component of their clearance curves to the testicular capillary blood flow.

Radioactivity in the testis was plotted against time on semi-logarithmic graph paper. The half time of this disappearance is related to flow by the formula of Kety (1951):

$$
\mathrm{F}=\frac{0 \cdot 693 \lambda}{\mathrm{T}^{\frac{1}{2}} \cdot \rho} \cdot 100
$$


where $\mathrm{F}$ is the flow in $\mathrm{ml} / \mathrm{min} / 100 \mathrm{~g} ; \lambda$ is the partition coefficient of xenon between tissue and blood, equal to 0.82 for the testis (Fritjofsson, Persson \& Pettersson, 1969); $\mathrm{T}^{\frac{1}{2}}$ is the half time of loss of radioactivity; and $\rho$ is the tissue density equal to 1.06 (J. Joffre and M. Joffre, unpublished data).

\section{Histology}

Testes were fixed in Bouin Holland's solution and stained with haematein erythrosin.

\section{RESULTS}

The variations in testicular capillary blood flow measured at approximately monthly intervals during the seasonal breeding cycle are shown in Table 1.

\section{Dormouse}

The capillary blood flow was minimal from December to February (mean: $18.3 \pm 1.2 \mathrm{ml} / \mathrm{min} / 100 \mathrm{~g})$, then rose to a maximum in June $(41.6 \pm 1.7 \mathrm{ml} / \mathrm{min} /$ $100 \mathrm{~g})$. From July, it decreased slowly until January.

The testes were small between November and February and, during this period, they were in an abdominal position. From March to April, the testes increased in size to reach a peak in June when they were in a subcutaneous position. In April, the germinal epithelium began to proliferate. In June and July, spermatozoa were present in large numbers in the lumen of the seminiferous tubules and the interstitial cells were at their largest; this cellular activity decreased in September. From December to February, the germinal epithelium was low and the interstitial cells were at their smallest. These seasonal variations in the testicular activity agree with those recorded by Hainard (1962).

\section{Ferret}

In this species, changes in blood flow during the seasonal breeding cycle were less obvious than in the dormouse. In July, the blood flow was at its minimum $(21.3 \pm 1.5 \mathrm{ml} / \mathrm{min} / 100 \mathrm{~g})$ and progressively increased to reach the maximum value which was maintained relatively constant between January and March $(35.2 \pm 1.2 \mathrm{ml} / \mathrm{min} / 100 \mathrm{~g})$.

Seasonal changes in the size of testes were not very obvious during this cycle.

Histological examination of these organs showed that there was no spermatogenesis in October. In December, a resurgence in spermatogenesis began and in January, the seminiferous tubules contained spermatozoa in large numbers until May. In June, spermatogenesis was again in regression and the majority of testes contained few spermatozoa. Interstitial cells were larger in January and smaller in October. These seasonal changes are comparable to those observed by Allanson (1932) and Asdell (1965).

Fox

For this species, variations in blood flow during the cycle were the most obvious. A rapid increase in the testicular blood flow was observed from October with an important peak occurring in January $(68.3 \pm 3.5 \mathrm{ml} / \mathrm{min} /$ 


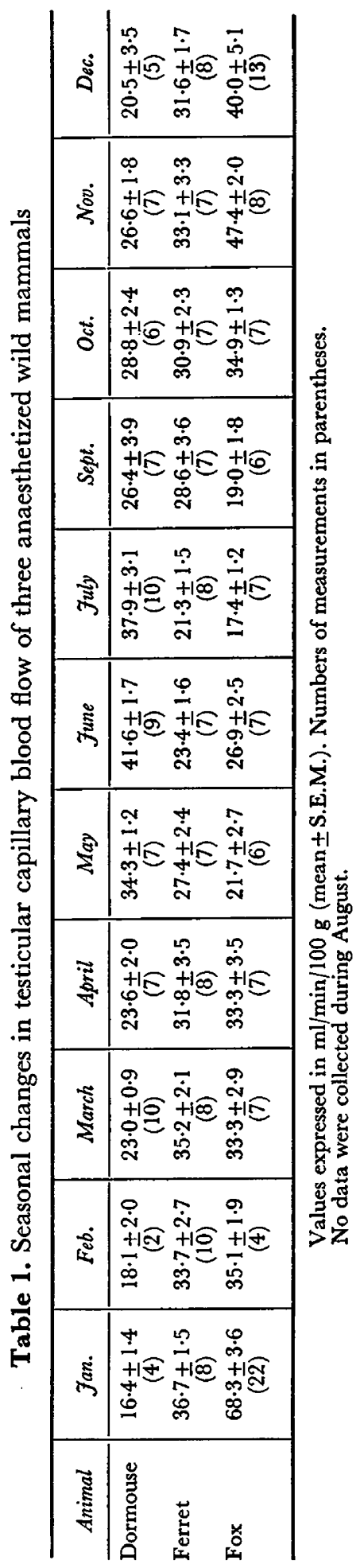


$100 \mathrm{~g})$. The flow then decreased to a minimum value $(21 \cdot 3 \pm 2 \cdot 1 \mathrm{ml} / \mathrm{min} / 100 \mathrm{~g})$ which was maintained until September. In the fox, the weights of the testes also underwent clear seasonal changes.

Histological examination of these organs showed that, in October, the germinal epithelium begins to proliferate. All testes obtained between December and February contained spermatozoa in large numbers in the tubules. During this period, the interstitial tissue was quite well developed. In March, the spermatozoa were less numerous and they were completely absent in April. The quiescent state of the seminiferous tubules was maintained from May to September. During these months, the interstitial tissue remained very developed but Leydig cells were inactive. These observations are in good agreement with those obtained by Creed (1960).

\section{DISGUSSION}

The radioactive inert gas clearance technique and the isotope fractionation technique give a measure of capillary blood flow, the component of the total venous outflow which is important for tissue nutrition and metabolism (Setchell, 1970). In the present study, it was impossible to use the second technique because only one estimate could be made on one animal; this procedure was incompatible with regular measurements of blood flow in the same animal and with the few wild animals caught in a year. Moreover, the use of the inert gas clearance technique, with the administration of the tracer substance in the spermatic artery, was difficult in these three species since it required the prolonged maintenance of a polyethylene catheter in a very small artery. The radioactive inert gas clearance technique with injection of the isotope into the testicular parenchyma was the only practical method available. This technique, previously used in the rat, rabbit, sheep (Blombery, 1967), dog (Wax \& Peterson, 1967) and man (Fritjofsson et al., 1969) has been tested here in the rat and it gave the same blood-flow values as other techniques (Joffre \& Joffre, 1971).

Testicular capillary blood flow was minimal when the testes were in an inactive state. Blood-flow values obtained during this period in the dormouse $(18.3 \pm 1.2 \mathrm{ml} / \mathrm{min} / 100 \mathrm{~g})$, ferret $(21.3 \pm 1.5 \mathrm{ml} / \mathrm{min} / 100 \mathrm{~g})$ and fox $(21 \cdot 3 \pm 2 \cdot 1$ $\mathrm{ml} / \mathrm{min} / 100 \mathrm{~g}$ ) were similar to those reported for the rat, rabbit and dog (Setchell, 1970). Within each of these three species, some differences occurred in the testicular volume, but the minimal blood-flow values were similar. For the same species, the groups of animals were heterogeneous. Nevertheless, only slight variations in capillary blood flow were observed. On the other hand, maximal blood-flow values were much higher than those observed for the rat, rabbit and dog. Text-figure 1 shows that the values in the dormouse $(41 \cdot 6 \pm 1 \cdot 7$ $\mathrm{ml} / \mathrm{min} / 100 \mathrm{~g})$, and particularly in the fox $(68.3 \pm 3.6 \mathrm{ml} / \mathrm{min} / 100 \mathrm{~g})$, were markedly higher than those attained in the ferret $(35.2 \pm 2 \cdot 1 \mathrm{ml} / \mathrm{min} / 100 \mathrm{~g})$. They were obtained during the full seasonal breeding period when both the seminiferous tubules and the interstitial gland are seen histologically to be highly active. The seasonal pattern of testicular capillary blood flow varied greatly between species (Text-fig. 1). For the fox and dormouse, the peak was rapidly reached but was followed by a rapid fall to low values. In both species, 
the period of activity was very short, and the testicular volume underwent clear modifications during this time. In the ferret, by contrast, the testicular blood flow increased slowly to reach a maximum value which was maintained between January and March, and then progressively decreased. In this animal, the period of activity was longer and the morphological modifications of the testis were less important. These seasonal changes in testicular capillary blood flow may be associated with the variations of hormonal and spermatogenic activities of the testis, but it is not possible to establish either the existence of a particular correlation or a difference in phase between blood flow and one of these activities because the number of animals in the present experiments was limited and the animals were not uniform.
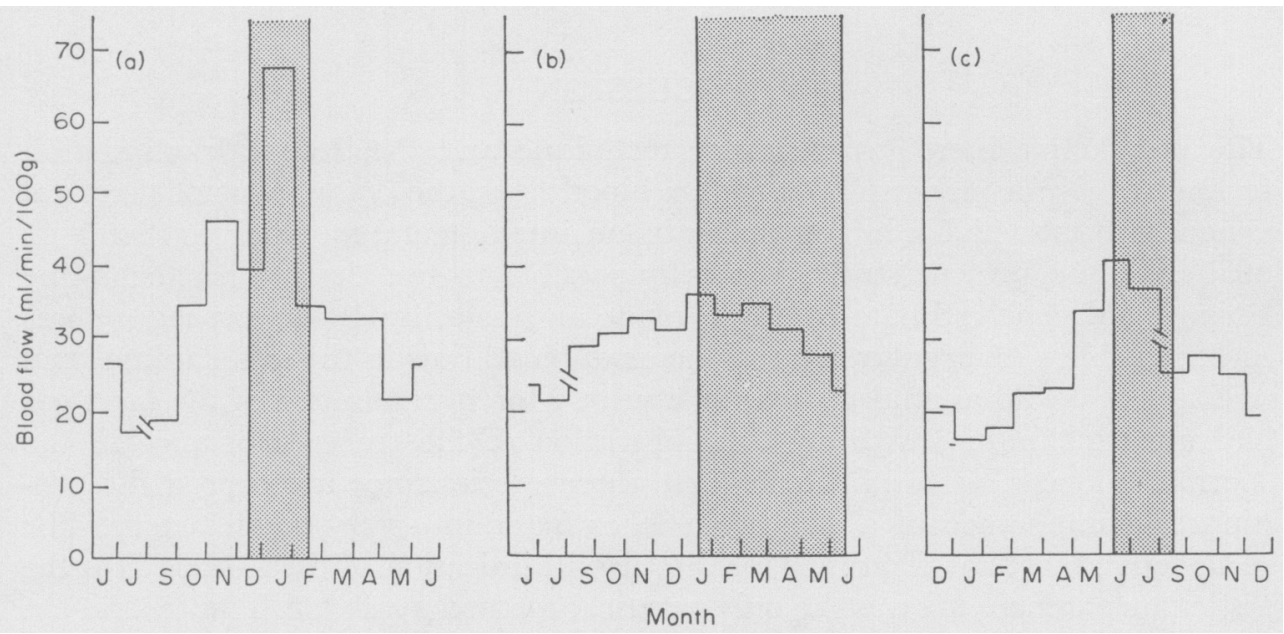

Text-Fig. 1. Seasonal changes in the mean testicular capillary blood flow (-) of (a) fox, (b) ferret and (c) dormouse and periods during which spermatozoa were present in their seminiferous tubules (shaded area). No data were collected during August.

Throughout the literature, there is almost no mention of any seasonal changes in the testicular capillary blood flow in domestic mammals although there are reports of annual variations of sexual activity (see Lodge \& Salisbury, 1970). It appears that the only values recorded for seasonal changes in testicular blood flow are those of J. L. Linzell and M. Peaker (cited in Setchell, 1970, p. 141) in the gander. According to Haddy \& Scott (1968), the capillary blood flow and the level of cellular metabolism are closely related. In seasonally breeding mammals, testicular metabolism during the inactive period is different from that observed during the period of testicular activity. It is, therefore, possible to assume that changes in the blood flow are only linked to changes in the cellular metabolism of the testes which are under hormonal control. Moreover, our results can be compared to those obtained by Setchell, Waites \& Lindner (1965) in the ram: after a long period of undernutrition, the total blood flow, in unit weight of testes and epididymides, is lower than in control rams. This decrease was accompanied by a decrease in the weight of testes and by a severe impairment of both the endocrine and spermatogenic functions of the testis. Although this 
decrease was accompanied by a decrease of metabolism, Setchell (1970) concluded that a reduction of gonadotrophins was probably largely concerned in the effect of undernutrition on testicular blood flow. In the present investigation, we observed a decline in the weight of the testes during the period of regression which was related to the decrease in the capillary blood flow. Our animals were regularly and adequately fed and did not present marked seasonal variations in body weight, suggesting that nutritional factors are not responsible. Under these conditions, gonadotrophins might affect the testicular capillary blood flow and the testes of seasonally breeding mammals would seem to be similar to the ovary, the blood flow of which is sensitive to LH (Wurtman, 1964).

\section{REFERENCES}

Allanson, M. (1932) The reproductive processes of certain mammals. III. The reproductive cycle of the male ferret. Proc. R. Soc. B, 110, 295.

AsDell, S. A. (1965) Patterns of mammalian reproduction. Constable, London.

BLombery, P. A. (1967) An investigation of certain aspects of the testicular vasculature. B.Sc. Med. thesis, University of Sydney, Australia.

CREed, R. F. S. (1960) Observations on reproduction in the wild red fox (Vulpes vulpes). An account with special reference to the occurrence of fox-dog crosses. Br. vet. F. 116, 419 .

Erk-NEs, K. B. (1964) On the relationship between testicular blood flow and secretion of testosterone in anaesthetized dogs stimulated with human chorionic gonadotrophin. Can. F. Physiol. Pharm. 42, 671 .

Fritjorsson, A., Persson, J. E. \& Petrersson, S. (1969) Testicular blood flow in man measured with xenon 133. Scand. F. Urol. \& Nephrol. 3, 276.

HADDY, F. \& ScoTT, J. B. (1968) Metabolically linked vasoactive chemicals in local regulation of blood flow. Physiol. Rev. 48, 668.

Hainard, R. (1962) Mammifères sauvages d'Europe, Vol. II, p. 227. Delachaux et Niestlé, Neuchatel, Switzerland.

Hyman, G. (1960) Peripheral blood measurements: tissue clearance. Meth. med. Res. 8, 236.

Jofrre, J. (1971) Mise au point d'une technique de mesure de débit sanguin capillaire du testicule par analyse des courbes de clearance du xenon 133. Application à des mammifères sauvages à activité sexuelle périodique. Thèse $3^{\circ}$ cycle, Université de Poitiers, France.

JOFFRE, M. \& JofFre, J. (1971) Débit sanguin testiculaire chez le rat: mise en évidence sur les courbes de clearance du xénon 133 d'une composante liée aux graisses épididymaires. C.r. hebd. Séanc. Acad. Sci., Paris, 273, 496.

KETY, S. S. (1951) The theory and applications of the exchange of inert gas at the lungs and tissues. Pharmac. Rev. 3, 1.

Kormano, M. (1967) An angiographic study of the testicular vasculature in the post-natal rat. Z. Anat. EntwGesch. 126, 138.

LiNDNER, H. R. (1961) Androgens and related compounds in the spermatic vein blood of domestic animals. IV. Testicular androgens in the ram, boar and stallion. F. Endocr. 23, 171.

Lodge, J. R. \& SAlISBURY, G. W. (1970) Seasonal variation and male reproductive efficiency. In: The Testis, Vol. 3, p. 139. Eds. A. D. Johnson, W. R. Gomes and N. L. VanDemark. Academic Press, New York.

Setchels, B. P. (1970) Testicular blood supply, lymphatic drainage and secretion of fuid. In: The Testis, Vol. 1, p. 101. Eds. A. Johnson, W. R. Gomes and N. L. VanDemark. Academic Press, New York.

Setchell, B. P., Waites, G. M. H. \& LindNER, H. R. (1965) Effect of undernutrition on testicular blood flow and metabolism and the output of testosterone in the ram. F. Reprod. Fert. 9, 149.

Setchele, B. P., Wartes, G. M. H. \& ThorburN, G. D. (1966) Blood flow in the testis of conscious ram measured with krypton 85 : effects of heat, catecholamines and acetylcholine. Circulation Res. 18 , 755.

Waites, G. M. H. \& Setchell, B. P. (1969) Physiology of the testis, epididymis and scrotum. In: Advances in Reproductive Physiology, Vol. 4, p. 1. Ed. A. McLaren. Logos Press, London.

Wax, S. H. \& Peterson, N. (1967) Measurements of testicular blood flow by intratesticular injection of xenon 133. Urol. Surv. 18, 544.

WURTMan, R. J. (1964) An effect of luteinizing hormone on the fractional perfusion of the rat ovary. Endocrinology, 75, 927. 